УДК 159.9:316.6+159.9

DOI: $10.33184 / \mathrm{NShvb}-2021-11-22.15$

Каратеев Олег Витальевич

кандидат психологических наук доцент кафедры общей психологии

Башкирского государственного университета

\title{
О ВЫЯВЛЕНИИ ТИПОВ РЕСПОНДЕНТОВ В РОССИЙСКИХ ИССЛЕДОВАНИЯХ СОЦИАЛЬНЫХ ПРЕДСТАВЛЕНИЙ О ПСИХИЧЕСКОМ ЗДОРОВЬЕ
}

\begin{abstract}
Аннотация. В статье рассматриваются исследования психического здоровья, в которых изучаются типь респондентовносителей специифических социальных представлений. Описываются задачи, поставленные авторами, и методы исследования.
\end{abstract}

Ключевые слова: сочиильные представления, теория сочиильных представлений, психическое здоровье, типь респондентов-носителей представлений

C. Московичи, рассуждая о социальных представлениях, демонстрирует, что их роль состоит в организации содержания повседневного мышления людей; представления позволяют согласовать наши взгляды и ценности и сами участвуют в создании наших социальных связей. Представления не только влияют на отношение людей к обществу, но и сами являются частью социальной организации [8].

Важно заметить, что представления появляются в связи с феноменами, объектами, процессами, вокруг которых разворачивается отчетливая общественная дискуссия, которые вызывают конфликт или находят иной эмоциональный отклик в обществе [7].

Известно, что в западной психологии интерес теоретиков социальных представлений к проблеме психического здоровья вызван практической необходимостью ресоциализации психически больных людей [1].

Согласно О. В. Каратееву, теория социальных представлений является одной из ключевых для анализа общественного дискурса в связи с проблемами психического здоровья и болезни, а исследование проблем 
психического здоровья с помощью теории социальных представлений может способствовать не только развитию самой теории, но также помочь современному российскому обществу в решении ряда практических проблем, в частности связанных с необходимыми изменениями оказания психиатрической помощи в стране. Изучение представлений о психическом здоровье (в том числе и представлений о счастье и благополучии, а не только о психических расстройствах, суициде и т.п.) в разных социально-демографических группах также может быть направлено на решение таких задач, как уменьшение стигматизации и дискриминации людей с психическими расстройствами, построение эффективных программ просвещения населения по вопросам психического здоровья. Также исследования социальных представлений могут на качественном уровне указывать на изменения, происходящие в больших социальных группах, тем самым отражая степень эффективности реализуемых властями программ в области психического здоровья [6].

В 2020-2021 гг. нами был проведен анализ 33 отечественных исследований социальных представлений в области психического здоровья (статья в данный момент находится на этапе рецензирования). В статье анализируются такие показатели, как объект исследования, предмет исследования, количество проведенных исследований в том или ином году, объем выборки, примененные эмпирические и статистические методы. Выявлено, что объекты исследования чаще определены, исходя из их социально-демографических характеристик (статус и возраст). Обычно усилия российских исследователей предопределены методологией школы Экс-ан-Прованса и ограничены выявлением структуры представлений некоторых больших групп. При этом редко ставится задача, направленная на выявление типов респондентов в связи со спецификой их представлений.

С. Московичи в диссертационной работе, открывшей для науки теорию социальных представлений, изучает представления о психоанализе в группах рабочих и студентов и находит различия, обусловленные групповой идентичностью респондентов и соответствующей идеологией $[2,9]$.

Исследователи осознают, что представления больших социальных групп могут быть неоднородными, а детерминация представлений крайне сложной. Поиск конкретных типов может открыть дополнительные возможности для понимания конституирования представлений и их 
распределения, способствовать выявлению реальных групп - а не только номинальных, - к которым принадлежат испытуемые.

Итак, только в 3 из 33 обозначенных исследований ставится задача по выявлению типов респондентов-носителей представлений. Рассмотрим данные исследования и опишем поставленные авторами задачи и используемые ими методы.

В исследовании Т. П. Емельяновой, Т. В. Исраелян [4] рассматриваются содержательные различия представлений о душевном нездоровье у людей с отличающейся религиозной ментальностью (православные, мусульмане, неверующие). Задача исследования выявление типов респондентов со специфическими представлениями о душевнобольных, для ее решения на эмпирическом уровне использовался авторский опросник с 29 утверждениями, на статистическом - кластерный анализ методом k-средних. В результате авторами определены 6 типов респондентов (толерантный, сочувствующий, равнодушный, нетолерантный, смиренный, враждебный). Дальнейшие действия авторов связаны со сравнением ядерных элементов каждого из типов со структурой представлений православных, мусульман и атеистов.

Заметим, что в каждый из типов входят респонденты из всех трех исследуемых групп, а структура и содержание их представлений наводят на мысли, учитывая содержание утверждений опросника, о необходимости интерпретации результатов не только из соображений религиозности, но и о дополнительном исследовании идеологических воззрений и политических установок респондентов. Кроме того, привлекает внимание «нетолерантный» тип, в группу которых вошли 34 респондента-носителя представления (среди них: 14 атеистов, 6 православных и 4 мусульман). Авторы, следуя за логикой поставленных задач, предполагают, что такие респонденты склонны к стигматизации психически больных и для них нехарактерна религиозная копинг-стратегия, однако, можно предположить, что такие представления обусловлены не религиозностью респондентов, а их полом. В исследовании указано, что в группу неверующих входит 76 мужчин и 37 женщин (представительство мужчин выше, чем в группе православных и мусульман - 49 и 53 человека соответственно), при этом нет данных о гендерном составе групп выявленных типов.

В исследовании Т. П. Емельяновой [3] рассматриваются социальные представления молодежи о жизни в мегаполисе в связи с психологическим благополучием. Задача исследования - выявление типов респондентов со 
специфическими представлениями, а для ее реализации использовался авторский опросник и кластерный анализ методом k-средних. В результате автор выделяет три типа респондентов (1 - «позитивно ориентированный тип», 2 - «активный тип, ориентированный на карьеру», 3 - «тревожный тип, ориентированный на потребление»), описывает элементы их предсталвений и приходит к выводу о неоднородности восприятия молодежью жизни в мегаполисе.

В диссертационном исследовании А. А. Зининой [5], выполненном под руководством Т. П. Емельяновой, изучаются представления о психологическом благополучии в старости. Задача исследования заключалась не только в выделении типов, но и в описании их психологических особенностей. Для выявления типов использовался опросник представлений и кластерный анализ методом k-средних. Всего получены 5 типов респондентов-носителей с отличающимися элементами ядра.

В дальнейшем автор сравнивает выделенные группы типов по полученным с помощью других методик и определяет наиболее благополучный тип респондентов, обращается к их идентичности, а также ценностям и атрибуциям.

Приведенный обзор позволяет сделать следующие выводы.

1. Российскими психологами редко изучаются типы респондентов со специфическими социальными представлениями.

2. Исследования, в которых ставится такая задача, выполнены Т. П. Емельяновой либо под ее руководством.

3. В двух исследованиях задачи ограничиваются выявлением типов респондентов и описанием характерных для них представлений. В одном исследовании дополнительно изучаются психологические особенности найденных типов носителей представлений.

4. Во всех обозначенных исследованиях используется кластерный анализ методом k-средних.

\section{Список использованных источников}

1. Бовина И. Б., Панов М. С. Обыденные представления о психически больных в студенческой среде // Социологический журнал. 2005. №3. URL: https://cyberleninka.ru/article/n/obydennye-predstavleniya-opsihicheski-bolnyh-v-studencheskoy-srede (дата обращения: 05.11.2021). 
2. Донцов А. И., Емельянова Т. П. Концепция социальных представлений в современной французской психологии. М.: Изд-во МГУ, 1987. $128 \mathrm{c}$.

3. Емельянова Т. П. Психологическое благополучие и социальные представления о жизни в мегаполисе // Знание. Понимание. Умение. 2015. №1. URL: https://cyberleninka.ru/article/n/psihologicheskoe-blagopoluchie-isotsialnye-predstavleniya-o-zhizni-v-megapolise (дата обращения: 06.11.2021).

4. Емельянова Т. П., Исраелян Т. В. Фактор религиозной ментальности в социальных представлениях о душевном нездоровье // Ученые записки. Электронный научный журнал Курского государственного университета. 2019. №3 (51). URL: https://cyberleninka.ru/article/n/faktor-religioznoy-mentalnosti-v-sotsialnyhpredstavleniyah-o-dushevnom-nezdorovie (дата обращения: 06.11.2021).

5. Зинина А. А. Социальные представления разных групп общества о психологическом благополучии престарелых людей: дис. ... канд. психол. наук. М., 2018. 206 с.

6. Каратеев О. В. Проблема психического здоровья в контексте социальной психологии: теория социальных представлений // Сборник статей заочной Всероссийской научно-практической конференции «Психическое здоровье в современных реалиях» (г. Уфа, 25 декабря 2020 г.). Уфа: Изд-во БашГУ, 2020. С. 71-81.

7. Höijer B. Social representations theory // Nordicom review. 2011. T. 32. №. 2. P. 3-16.

8. Moscovici S. Notes towards a description of Social Representations // European Journal of Social Psychology. 18(3). P. 211-250. doi:10.1002/ejsp.2420180303

9. Wagner W. Social Representation Theory // The Encyclopedia of Peace Psychology / Edited by Daniel J. Christie. Blackwell Publishing Ltd. 2011. doi:10.1002/9780470672532.wbepp26.

(C) Каратеев O.B., 2021 